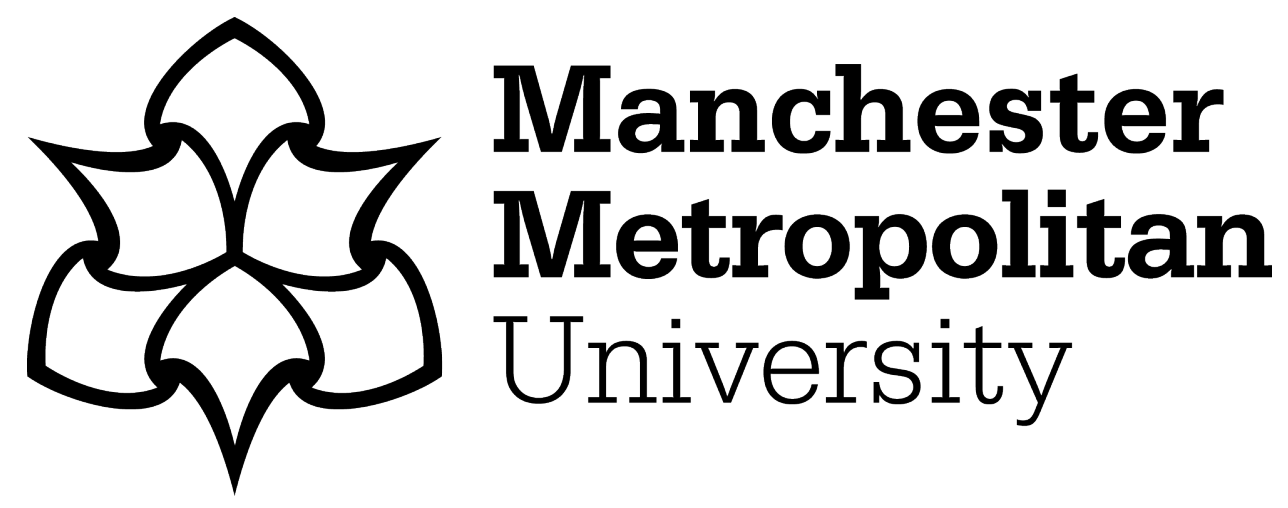

Roffey, M (2016) Private Notes Made Public. Caribbean Quarterly, 62 (3-4). pp. 344-356. ISSN 0008-6495

Downloaded from: https://e-space.mmu.ac.uk/620991/

Publisher: Taylor \& Francis

DOI: https://doi.org/10.1080/00086495.2016.1260267

Please cite the published version 


\section{Private Notes Made Public}

An essay

By

Monique Roffey

My first experience of coming across a writer's notebooks was maybe over two decades ago, when I was just starting out, in the form of one of Albert Camus' Cahiers. It was an old beaten up hardback copy I found in a second hand book shop. I remember being mesmerised by the way Camus seemed to be forming sketches and jotting down ideas, just like a painter might prepare for a large piece of work. I saw how he was slowly, slowly coming to write L'Etranger. His notes were associations of ideas. They were patches of his creative thinking going down roughly, page by page, scrappily, in fact much like a scrap book. For me, as a novice writer, I was able to see a kind of ultimate and completely unconscious first draft of a novel in this notebook, one which was to become a classic work of literature. It was exciting. It influenced me, a long time ago. In being able to see how a writer goes from mere jottings to a fine literary novel, I saw what "in progress" really means, and how crudely this process starts.

Susan Sontag in her essay “The Ideal Husband”, in The New York Review of Books, Sept, 1963, famously wrote that Camus' Notebooks were not great literary journals, like those of Kafka and Gide. Instead, she says, they are merely 'literary workbooks'. Her main complaint is that his Notebooks/Cahiers contained nothing personal. And she's right, of course, Camus' notebooks aren't deeply confessional in terms of who he loved and who he may have been sleeping with. God alone knows if he ever wrote anything white hot and personal down, and if so, I'm sure they were very private. But I disagree with Sontag that his Cahiers aren't great, or important, mostly because from those Cahiers we do get a sense of the writer's mind, of Camus' inner life, his ideas, where he was going with them, and what was his world, his train of thought. I loved reading how a novel was being born in his thoughts. The first writer's notebooks I ever read and loved weren't intimate diaries, but they were what a great man had been thinking about when shaping his novels; this was helpful. They were books of ideas and scraps of consciousness. 
I liked them for that. I still read them and have the new paperback versions on my shelf in my personal library. Three volumes which span 1935-1959, half his life. I still dip into them. They make me think and they make me think like him, spaciously, cross-referencing experiences, ideas from without and within. I have, ever since, taken notes in a similar fashion, committing patches of thought, lists, weird scraps of ideas, memories, events, conversations, doodled pictures, in short, all kinds of bits and pieces, into many small and medium sized Moleskine notebooks. For now, my own Camus inspired notebooks are on a shelf at home. They are the offspring of Camus' Cahiers in some ways. However, while mine contain ideas and bits of ideas, patches of plots for novels, mine, unlike Camus', are also very confessional.

Over the course of a fifteen year career as a writer, (I consider these years, still, as early years, as a kind of ten year apprenticeship and a five year emergence), I have come across many other writers' journals, and a couple of these have also been extremely helpful to my working life. I often show pieces of these notebooks to aspiring writers when I teach creative writing classes. John Steinbeck's' Working Days, is a hugely inspiring collection of diary entries which he made over the course of a final (and successful) attempt at writing Grapes of Wrath. It reflects the process of a writer at odds with his domestic life and struggling to know or believe whether his work is any good (GOW won the Pulitzer Prize in 1940). Anaïs Nin's journals are also engrossing. In these, I felt I'd come across an uncannily similar type of woman. Her notebooks reveal a modern woman's journey of selfdiscovery. Like me, she was in psychoanalysis for many years, and, like me, she was a traveller, a woman who was sexually explorative and who didn't have children. Like me too, she was a hetaera woman. She lived the life of the mind and the life of a female writer in the early 20th century and her thirty-year diary is an account of an artistic era.

All three of these sets of notebooks, those of Camus, Steinbeck and Nin, made an impression on me as a young writer. They demonstrated to me what serious writers do: they write to themselves. They do not potter about in a studio, like a painter might. No. They carry their studio about in their pocket. The notebook is a writer's first studio. Her desk and office is her second studio. A writer starts her work as notes-to-self. A writer can, and often does, communicate 
with thousands, even tens of thousands, sometimes even millions. But ultimately, a writer starts writing to self. All writers are, to begin with, 'self-writers'. We not only write notes-to-self, we read aloud, great chunks of our own work, we pace about, we write in bed, or standing up (like Hemmingway), we read and write all over other people's books. I often talk to myself, both while alone and in public, as most people who know me well have discovered. It is a strange habit, but it is part of my writerly process.

And so, in the last fifteen years, it seems to me, that I have produced two bodies of work. The second body is the official, neatened up, fully-processed version of my work. These are my six published books that have undergone rigorous production in the form of editing, sub-editing and proof reading by a major mainstream publisher, Simon and Schuster UK (my next book will be published by Indie press Dodo Ink). They are a fait-accompli. What is true is that in published novels, the reader will never know or see the long process of how a book comes into being before it is published, how many years and how many drafts, and even how many editors. The book I'm to publish in 2017, for example, The Tryst, I worked on for fifteen years, on and off. It followed me to several homes and onto three different computers, from floppy disk to Apple Mac. It has been sold twice; it has been read and critiqued by other writers on the way, even a male writer I met covertly during my research for my memoir. The Tryst, a short erotic novel which borrows from the myth of Lilith, Adam's first wife, is a book which has a unique genesis and long journey to publication. I'm incredulous it has finally made it to print. But the arduous process of writing this book will never be fully known because I do not have all the drafts and notebooks which reveal all the wrong turns, the pages that got killed. This is true of every novel ever written by anyone.

My first body of work exists in notebooks and on paper and it is a rougher, much more intimate corpus, and this is the writing I call the self-writing. It includes all the hard graft: the many drafts, typos, scratched out phrases, double turns, question marks in the margin, notes to self like "check this", the red lines through not just paragraphs but pages, the shuffling that goes on of scenes from middle to front, in short, the months of what I call 'writing to find.' Most of that gets lost or binned. A writer's first body of work usually never gets seen or read 
by the public. Only occasionally does it get published, as in the cases of Camus, Steinbeck and Nin (all extremely famous). Many writers live and work and die and their first body of work, their early thinking and scribbling, is never witnessed. It is lost and/or trashed, thrown away, hidden and/or lost. This seems to me to be a great pity because writers write in more than one mode.

I have been in Jungian psycho-analysis for the last five years, a process which involved writing down my dreams, twice a week for the first two years, once a week thereafter. My analyst agreed to take me on at a much reduced rate, which is why he was affordable. Before and after his sessions, I wrote in a red Moleskine notebook. There are a few of these now and they are my version of Jung's red book. I think of them as containers for my prima materia, where I wrote down not just my dreams, the raw stuff, where I made the links in my unconscious to my everyday life. Here, I was writing in a different mode. And if a writer keeps notebooks like these long enough, she can begin to actually witness unconscious habits, desires and motivations - and watch these desires emerge in their work. Again, very helpful. Once a writer rounds on the unconscious, she can work in choice, as opposed to being repetitive, repeating themes and ideas. For example, I'm known as a Caribbean writer, mostly because three of my books are set in the region. However, what I think most readers may fail to notice is the closer subject matter of my Caribbean books. An observant reader might notice several linking themes; for example, three sets of child/adult pairings have shown up in my work. Three. Clock and George Harwood in The White Woman on the Green Bicycle (WWGB), Océan and Gavin Weald in Archipelago and Breeze and Ashes in House $O f$ shes (HOA). In all three of these books, the child has no mother to speak of. Clock and Breeze are more or less orphaned, no father. The subject of fatherhood, the good father, the bad father, having no father is the biggest and most persistent theme in my work.

My own father was Victorian, a colonial, enjoyed his rum on the rocks at eleven o clock in the morning, lacked emotional warmth and died in my late twenties. I was packed off to boarding school aged twelve. My older brothers had been sent away even earlier and I was more or less an only child. My fatherdaughter relationship was volatile and fraught. We were of very different generations, for a start, pre and post-feminism and all that. So, while I have been 
examining my own father, and paternal masculinity in general, in my prose, yes, it so happens, this paternity quest, (and in my case the struggle against the white colonial), is also a very Caribbean theme. I had my own private colonial; others often see the white male colonial as a historical figure, mine was personal. My red notebooks contain the early writing about my father. This is a very personal mode of writing.

Recently, I have started a new novel, A Stranger to Tears, and yes ${ }_{2}$ another child/adult pairing has turned up, Reggie Horatio Baptiste Rain and his mother Arcadia Rain; what is significant is that Reggie has a good mother and his father will return. If not for my years of analysis, and the red notebooks, I may never have been able to write this sympathetic tableau: a good mother, and a returning father, ever. My novels might have continued, same, same. And so, one mode of writing has informed another. It is slow progress; even so, it is actual progress. It is writing in choice and not from purely unconscious motivations.

I was a diarist and a note taker, a 'self-writer', from childhood. An introvert, a muser, a plotter, and a dreamer. I could stare at a wall for hours. I was the quintessential 'weird kid' at school: clever, slightly cross-eyed and precocious. Bullies would never have a go at me, though, because I was too mouthy and unpredictable. In fact, so mouthy was I, that our Latin teacher, Mr. Martin, once locked me in a games locker in the lobby of our Latin class. I had gone too far and he got me back.

All my childhood diaries have been lost or thrown away. They were all about hating my mother anyway, and, when she later found (and read) them, she confiscated them. Much later, in my early twenties, I kept copious notes and diaries, all recording tedious post-pubescent angst. But I burnt them all, in a fit of self-consciousness in my late twenties. I didn't start taking proper notes till I discovered Camus' Cahiers; so most of my surviving notebooks start from around that time.

Insert Figure 1. (caption to go below image) (some of my Moleskine notebooks, including my red books)

In December 1999, in a creative writing class at Lancaster University, while studying for an MA in Creative Writing, I met the writer Ian Marchant. He was broke, living in a caravan on a smallholding of land, six-foot-four, bald, gold- 
toothed, and reeking of cannabis. I more or less fell in love with him on sight. Our love affair lasted six years and our time together included a year living in a rat infested short-life housing co-op in Islington, London, writing novels (me) and non-fiction (him), and running a busy writing centre called Totleigh Barton, in Devon, for The Arvon Foundation. It was Ian Marchant who suggested that I start keeping all my first body of work: my notebooks and my manuscripts and all sorts of other bits that comprised the detritus of my working life. He said it would be a good idea because that's what proper writers did and it might all be worth a few quid one day. I was extremely sceptical about this but I did keep the work.

Looking back, I can now see that I was sceptical because I was a woman. At the tender age of thirty-five, I was still very much in the psychological power-grip of global patriarchy. The eponymous and all-pervading white male judge lived within. This judge was, of course, out there in the world, too, and he was also my boyfriend, my live in partner; there was no getting away from him. Be it Empire, modern day Westminster, God, Daddy, my lovers and/or the man in the street, patriarchy was (and still is) the most limiting element in my life, as with all women. I was thirty-five in the year 2000; there was no social media, and the internet wasn't the crackling space of ad-hoc conversation and commenteratti that it is today. Writers, academics and activists didn't yet communicate daily and swap ideas like they do now. Feminism was something I knew about; but I still hadn't met enough active bone fide feminists of my own generation. Feminism was in books; you studied it at university. I rarely met actual self-proclaimed feminists in day to day life. In short, men's lives were worthy of note and men who wrote were worthy of keeping their notebooks. Looking back, I hadn't yet grown into my full self or potential; childhood mouthiness may have been an early indicator of having a spirited nature, and yet, even then, at thirty-something, I still didn't see myself as an equal to men like Camus. I kept my manuscripts and notebooks and God knows what else, because a man, my boyfriend, suggested I do so.

My early years as a writer were romantic and bohemian. There was Ian Marchant, the writer-tramp boyfriend, his damp, smoke-blackened caravan, the Islington housing co-op, the rats in the co-op, the student garret in Lancaster, and then the Arvon Foundation, Sheepwash, Devon, where we lived together with two cats in a tiny cob-walled tithe cottage. In those four years, we met hundreds of 
established and apprentice writers. My MA in Creative Writing (for which I wrote

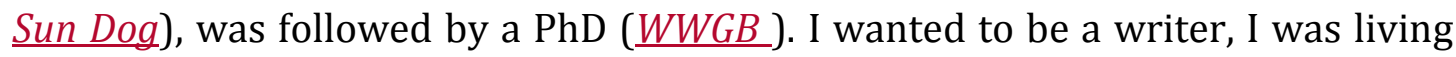
with a writer, living a writer's life and writing books. Golden years. I thought we were like Plath and Hughes, or de Beauvoir and Sartre. Roffey and Marchant were a literary partnership, and, again looking back, these years were extremely formative. I wasn't really getting anywhere (that was to come), but I felt like I was; I felt like the real deal, a struggling artist, living by my wits, young and talented and living without compromise. I'd published one novel, my first, $\underline{\text { Sun Dog, then }}$ tried another, "Removed", then another, The Tryst. ("Removed" is never to be published as it's too rough and problematic and The Tryst will be published in January 2017). During this time, I kept all my manuscripts and work, press and publicity and my journals.

In January of 2006, I broke up with Marchant, spectacularly, and moved out of our tiny cottage. The boxes of manuscripts and notebooks (the same ones that he'd suggested I keep) came with me. By then, they were a habit. I was keeping this first body of work, hoarding it, more like. I wasn't quite sure why, or if I believed in what I was doing. All I know is that the boxes of "stuff" began to pile up. Heartbroken, I moved from Devon back to London and put all my belongings into storage, including all my manuscripts and journals. I moved in to a flat in Harlesden, north-west London, with a girlfriend and her partner, and settled down to write $W W G B$. My friend got pregnant, naturally, with her first child, aged fortyfive. And for a time, post split-up, I was almost happy writing a novel and living with friends and their newborn baby girl, my God daughter, Lois.

Then, shockingly, in the summer of 2008, all my belongings were burnt in a fire. Everything. In fact, not completely everything. When I arrived at the site of the fire, I was able to pick through the ashes of my old life and retrieve the odd spoon and fork, and a singed bound first draft copy of Removed. What was lost in the fire was irreplaceable: old furniture, a library of books, family heirlooms, dozens of leather-bound photo albums, and yes, boxes of my 'papers' which held proof, a skeleton, of my first attempts to get published as a writer and which had been kept uncertainly by me. It was only then, after the whole lot of my first body of early work was burnt to ash, that I realised I'd lost something of value: evidence of my early existence as a woman who wanted to become a writer. 
From 2008 onwards, I began to collect my papers and notebooks again, except this time with more intention and care.

As I write this essay, now, in May 2016, all that survives of my first body of work, (though now only seven years of it), is stored in the West Indiana Collection of the University of the West Indies in St Augustine, Trinidad. It is a famous, impressive and widely-consulted collection which spans two hundred years, and holds around a hundred and twenty collections of papers. Currently, I am the first and only woman writer to have a single-author collection within this important repository. Global European patriarchy, in the form of Empire, colonialism, indenture, slavery, and numerous other oppressive crimes against black and brown-skinned humanity ravaged the region for centuries, including the centuries that span this collection. The European man dominated everything and everyone. So, yes, the West Indiana Collection is currently a collection of papers mostly (but not entirely) of well-known men of colour of the Caribbean region (not women), many of them documenting and writing against or back to Empire. It could even be argued that me being the first woman to contribute, points to the fact that the legacy of Empire still pervades. I am white, I come from ex-colonial lineage (as can be read from the biographically informed $W W G B$ ), and I have enjoyed and benefitted from a private education in the UK. It adds up, in a way. Even though it was a man who told me to collect my papers, and, even though there was a bohemian time of poverty as an early writer, and even though I am still struggling financially, I am still a privileged white woman.

Truth is, my writer boyfriend/partner, the man behind me in my early writing life, was strongly influential. Actually, Ian Marchant was right, and I'm glad he suggested to me that I keep my papers. Today, in books, essays and on social media, we are all witnessing another upsurge of post independence writing from writers in the Caribbean region and diaspora and many debates are being stirred up about the lasting legacy of Empire. Ideally, there should be some way to archive and store the online Caribbean Facebook community of writers and some of the blogs of Caribbean writers, as they document a vast array of the dilemmas, debates, discussions and also the terrible fights and fallings out among the current crop of Caribbean writers and poets. Someone in the archives department at UWI, St Augustine, should look in to this project seriously, if they haven't already. 
So, by the summer of 2013 , I had again accrued lots more "stuff", all of it my first body of work.

As it happens, 2008 (the time of the fire) to 2014 (the publication of House of Ashes) was a very dynamic time for me. Post-Marchant, and as a mostly single woman, somehow, I'd managed to publish four books in five years: three novels and a memoir. In the decade from 2006-16, I'd travelled to and from Trinidad many times. I'd spent five long winters in Trinidad, living with my elderly mother, who was also my muse for WWGB. I had taught a lot of creative writing in that time, both in the UK and in Trinidad, mostly privately in Port of Spain, setting up the St James Writers Room in 2014, but I also taught for BOCAS literary festival and then, in 2015, on, the BA in Literature and Communications at COSTTATT. I had attended, read and taught at the BOCAS festival many times. My novels had been short-listed for five international awards and I had also won the OCM BOCAS Prize for Caribbean Literature in 2013. Turning up on prize-shortlists had been a shock, generally, and the Bocas win astonished me. I identify with the underdog, the outsider, the non-winner, and always have. Winning prizes make you legit, which is to be somehow a, well, winner. An insider.

However, having won the prize, I also knew I wanted to support and mentor emerging writers in Trinidad. I am a teacher by vocation. Six months later, in September 2013, I led a writing retreat in Grande Riviére, Trinidad. I then began to teach regularly in Port of Spain after that, teaching workshops on porches and spare rooms, in kitchens and on my mother's balcony, in Belmont and St James above a gym. Poet Loretta Collins Klobah co-created and co-led another retreat with me in January, 2016. As I write, I am preparing for a private workshop in Belmont, today. To date, I've taught around forty private workshops in the last four years, simply because I'm a teacher by nature as well as an author and I'm passionate about mentoring emerging writers here in Trinidad, where writers are hungry for constructive critical feedback that they so need.

Also, in the autumn on 20I2, I had just bought $25 \%$ of a small flat in the east end of London, my first home. The flat was compact and had very little storage space. By then I'd hoarded about a dozen boxes of manuscripts which contained early drafts of my latest novels and my memoir, dozens of files of press cuttings, writing contracts and other memorabilia. Also, dozens of Moleskine notebooks. I 
literally had no space for it all in my new home and was beginning to wonder what to do with it all. Keep it? Really? And for how long, and where? And yes, I was beginning to wonder if any of it was any good or of any use or value. Again, global patriarchy held its sway. Burn the lot again, why not? No one will ever be interested in me and my trivial jottings and banal musings. Throw the lot away or burn it all.

Insert Figure 2. (caption to be placed below image) (the contents of one of my boxes)

It was in the late summer of 2013 that I received a round robin email from Alison Donnell at Reading University via Nicholas Laughlin, one of the directors of the BOCAS festival; it was a call out, asking Caribbean writers if they had collected their papers and, if so, where they were to be found.

Gratefully, and immediately, I got in touch with Alison via email. We made a plan for her to come and see what I had collected. Again, I wasn't sure if any of it was of any relevance to anyone else, or what she'd make of it all. The boxes contained early journalism (three portfolios); my $\mathrm{PhD}$, bound in leather and in board (pre and post viva), the content of which was The White Woman on the Green Bicycle in printed page proof form (by then I had sold it) and an accompanying essay on its place in Caribbean literature; manuscripts of seven novels in different stages and drafts, some of them with editor's notes, some with proof/copy editor_s notes; proof copies of novels for the press; bound copies for the public; press cuttings; memorabilia; old book and audio book contracts; old school reports; old passports; the burnt and singed copy of Removed, my unpublished novel; an early copy of The Tryst, my erotic short novel. They also held rejection letters, hatchet job reviews, the cancellation of a contract (for The Tryst and the resale two years later) and cards and letters of congratulation. They contain some of my first body of work, or half of it, and therefore the background material to my second body of work: what is out there in the public realm.

Over fifteen years as a writer I have had two agents, first Simon Trewin and then Isobel Dixon, and two publishers, Simon and Schuster UK, a mainstream giant who published five of my books and a hip indie press, Dodo Ink, who will publish The Tryst in 2017. At SS, I survived three different editors. The best of these editors, Francesca Main, (who oversaw WWGB, Archipelago and WKHM) was 
headhunted and is now a senior editor at Picador and has won Editor of the Year, 2015, in the UK. Over fifteen years, I've written seven books, however, only five have so far been published. I am currently working on another novel, A Stranger to Tears. The collection of papers I have deposited at UWI reflects all of these ups and downs in my working life. They show that behind the official body of work is another story. The boxes are the archives of my growth as a writer; they are proof that I survived and didn't conk out after one book or even one major bouf. I have survived numerous challenges, different editors coming and going, leaving an agent, being hatcheted in 2011, by a highly paid attack dog, Camilla Long in a national British newspaper, The Sunday Times, and also in 2014 by a fellow writer and so-called friend, who had no commission from a newspaper. Despite all this, I have kept going.

The last fifteen years have been full of surprises. Not least that I am still here. My Jungian analyst had been a mentor too, (his hand written receipts are in the collection or will be added). I probably wouldn't have survived my career without him. I read my two hatchet jobs out loud to him. He kept me standing. There was no husband as back up, no Ian Marchant behind me in these years of major production. I was a single woman, but with good family here in Trinidad and good friends, also a network of fellow writers, most of whom I trusted. Publishing is fraught, not just with real pressures around getting published, staying published, and selling books, but also anxieties which any writer stirs up in others. Being published, successfully, attracts not just awards, but criticism and enemies; that is part of the job I had never bargained on and was ill-prepared for.

Once Alison had seen what I collected and has assured me of their value from the point of view of a researcher and an academic, the transfer of my archives to UWI, Saint Augustine was fairly swift and painless. Through Alison, I made contact with the librarians there and Reading University were able to arrange the storage and shipment to Trinidad. Not long after, I was in Trinidad and able to make a visit to the archivists at UWI. I was introduced to the Campus Librarian, Jennifer Joseph, Glenroy Tait, Head of West Indiana and Special Collections, and Lorraine Nero, Special Collections Librarian, I was shown a couple of notebooks in Derek Walcott's archive at the West Indiana collection; happily, they looked just like mine, small, black, leather-bound and full of drawings, phone numbers and 
notes. The staff were very helpful, and all of a sudden I found it was actually a relief to be signing my collection over. My first body of work would be safe, curated, cared for. The other option was to dump or burn it all and I wasn't ever entirely sure why I had been hoarding it anyway. I could easily have thrown it all away.

I knew I was leaving behind a legacy of some kind, and that my first corpus of work was in good care. We made the agreement and my material was transferred to UWI in March 2014. What's great is that all my boxes are gone; they no longer clutter my small home, and I also have a safe place to store my current and future output according to the terms of the agreement. I am a child-free woman and I know that now something, if not somebody, will survive me: my work, and also the evidence of what made it.

What I have NOT added to this publicly accessible collection, so far, is any of my notebooks, my Cahiers. For now, I cannot bear to let them out of my sight. They contain the stuff of dreams and the unconscious, my intimate and inner life. Yes, love, sex, and all of that too. Some if this appears in With the Kisses of his Mouth. A lot doesn't. My notebooks, like Camus' notebooks, also contain the rough patches and associations of ideas for my novels.

For now, these notebooks are all that I keep of my writing life in my small flat in east London. I shall have to think long and hard about handing them over to the UWI archives, if ever. Unlike Camus' Cahiers, they are my confessions and they contain much shadow and light, equally. I cannot see that I will be giving them away any time soon, or before my very old age. I will spend the rest of my life collecting them and deciding what to do with them, and yet also, I know, from my own experience with Camus, et al, that maybe one day a young woman, maybe even a bit like me, who wants to write, might find them interesting. For now, they are with me; they are the real story of my life.

\section{Insert Figure 3. (with caption)}

(boxes with my notebooks, my PhD bound in board and hard back, notebooks, manuscripts etc)

Caribbean Quarterly, September-December 2016, Volume 62, Nos 3 and 4 